\title{
CORPOREALITY AS THE HOLOGRAM OF MYTHOLOGICAL CONTENT (BASED ON THE PROSE OF THE UKRAINIAN DIASPORA OF THE 1920s-1950s)
}

\author{
OLHA SLONOVSKA
}

\begin{abstract}
The role and the place of the artistic truth and artistic speculation are a promising area of theoretical and practical explorations. The focus of this study is on the mythical-poetic hologram of the human body as a specific information carrier which comprises a range of important markers.
\end{abstract}

Keywords: literary text, mythical-poetic hologram of the human body, methodology of archetypal criticism, erotica.

A literary text is a world in itself; in its content, it is close to the real one, yet far from being identical to it; it is cosmological artistic phenomenon created by the author with the help of words. The heroes (characters) of a literary text cannot be regarded as real people, even if it is a historical or biographical work and the author models them after real-life persons. The reason for such disparity is twofold: on the one hand, it is temporal distance, the inability to accurately reproduce the events of a real person's life, to know his/her thoughts, plans, details of relationships with other people; on the other hand, and more importantly, a reader wants to see the character whose opinions, world view, spiritual impulses would interest him/her as a recipient; the attitude of the character's contemporaries is not a reader's primary concern.

For this reason, the author presents characters whose vocabulary is similar to that of readers' (except for a limited number of archaic and historical words used to create the effect of historical authenticity), whose dominating world view markers are the reflection of readers' attitudes rather than the attitudes of the historical epoch described in the book, who face the problems similar to those confronted by today's readers or their country. The system of methods and means which are used to create the image of a character complies with readers' holistic perception of this character; the image has to 'activate' all human senses - visual, aural, tactile; more importantly, it has to 'switch on' our kinetic and haptic sensations, all these being markers of human life.

The body of a literary character (hero/heroine, protagonist, antagonist, narrator) is an important source of information about him or her. The human body as a sign of cultural, group, ethnic belonging has a specific meaning in a literary work because human subconsciousness constantly provides us with enormous quantity of important markers of a person as a living being; they include the bodily constitution, facial expression, gestures, beauty or ugliness, bodily defects, speech impediment; they are perceived as ready answers to the question who is presented to a reader; they determine a reader's attitudes and assessment. It is but natural that cheap, popular, hackneyed images of Ukrainian beauties 
in flower wreaths, corsets, and national costumes are not associated with the body in its mythological sense; such images convey no meaning. On the other hand, retransformation of physical features, generalization of their meaning create symbols, which can reveal the covert essence of national purpose.

Using the device of time compression, joining the past and the future in order to create the picture of today, Ivan Bahrianyi in his piece Rozhrom (Defeat) 'thickens' the chronology and presents a reader with a collective image of thousands of thousands of Ukrainians who go and go, across almost all the continents, each one has their own way of the cross; but their eyes search for one beacon - their native land, the land of their ancestors. 'They march immersed in thoughts about them selves and the world, proudly and contem ptuously - along the endless prisoners' routes of Siberia, Kolyma, and Eurasia ... From one single or mass prison cell in jails and dungeons to another (ten steps forwards, ten steps backwards, their lips bitten, their eyebrows snapped together) ... Through underground tunnels and hard labour labyrinths... Across the dams, the viaducts, the pits of the many White Sea-Baltic Canals, Baikal-Amur Mainlines - the launched and not-yet-started projects ... Up and down the staircases of torture houses stained with their own blood ... Along strange roads of other people's war ... In other people's trench coats, in foreign armies ... In POW columns ... At the international human dump ... In the barb-wired corrals of concentration cam ps ... They fall down and rise again, and stubbornly keep going they hold on ... From all the points of the globe, from all abysses .., with their heads stubbornly bent down, they break through to one point ..., they seek it with his hearts. And its name is Homeland"* [3, p. 9-10]. Thus recipients/readers are presented with a dynamic panorama of the events.

A reader understands that for Ivan Bahrianyi, the post-war Germany, where in constant risk for his life he wrote his books living from hand to mouth, that ruined, demoralized, crossed out from the family of civilized countries Germany was associated with nothing less than Dante Alighieri's hell described in his Divine Comedy. Bahrianyi's undefeated Ukrainians are amidst the flame - a visible sign of unflagging spirit, which makes them equal to Homer's Odysseus as described in Divine Comedy. At the same time, in Ivan Bahrianyi's Defeat we come across a tragic symbol - a street whore, who does not scruple to please an African-American soldier. "New Europe" exchanged her virginity for a cigarette, for a cigarette stub... There she is - standing with a negro in the pool of pale street lamplight wriggling shamefully as a mutt, trying to catch his eye [3, p. 36]. This transformation of symbolically iron, armed cap-a-pie, bestmotorized Valkyrie-State into Obsequious-Whore-State emphasizes the collapse of Hitler's misanthropic idea, for which the German people (the nation of philosophers and poets, which at the level of subconsciousness should have identified the plans of the 'frenzied Fuhrer' as clearly infernal and should have been more cautious about them) paid millions of lives and, at the level of the myth, suffered the loss of national vital energy.

Close attention to the main bodily and gender parameters was paid in the texts of the Bible: it was prohibited to sacrifice crippled or sick animals; a disabled person or a person with abnormality, birthmarks could not become a priest, a prophet, a spiritual leader. On the other hand, during a person's trial or service to the Absolute, God might mark the chosen one; for example, Jacob developed a limp wrestling with a mysterious being; there is also 'a wide-spread belief that Moses, when he came down from Mount Sinai with the tables of the Law, had two horns on his forehead', though according to Jewish Encyclopedia (and many other sources), 'this strange idea ... is based upon a wrong interpretation of Ex. xxxiv. 29, 35' [19].

In ancient mythology, there was quite a substantial number of various monster races - the Centaurs, the Sirens, the Nymphs, the Pans, the Amazons, and others; such unique sinister monsters as Medusa, one of the three Gorgon sisters, and Cerberus, the Dog of Hades, were regarded as creatures of the other world, and their function in this world was far from being honourable or merciful. Though, most of the ancient chimeras were intentionally distanced from the orderly world - they were believed to dwell in the lands where chaos began, where the sacredness and the orderliness of the territories explored by humans end. According to V. Sukovata, '... Those whose bodily appearance did not

\footnotetext{
All quotations are translated from the original Ukrainian texts
} 
comply with the Greek notion of "the order of uniformity" were considered to be marginal beings and ousted from the Centre (Greece) to the suburbs of civilization. Symbolically, Medusa, Circe, the Sirens .., the Harpies ... corresponded to the "mother right" civilization before the emergence of the "law of the Fathers"' [14, p. 402]. In other words, in the civilized world, there was no room for the Amazons or the Centaurs, who were a priori perceived as bodily monsters. Even the ancient philosopher Plato did not think that the role of the Amazons befited his female contemporaries, though he did not deny the latter the right to military service or public activity [13, p. 262]. It is also important that ancient philosophers referred to the city-state of warlike females, whose ferocity surpassed that of males', as a place so rem ote that it fell into the category of hic suntleones*. Considering the data from ancient sources and analyzing the factors behind the phenomenon of the Amazons, we can discover many facts, important rather than interesting, which explain why C. Jung referred to the Amazons as 'troublemakers' and compared them to the wife of the biblical Lot - a female who adopts the lifestyle of males turns away from the life of joys and pleasures. Metaphorically speaking, they looks back, as Lot's wife looked back at Sodom; they cannot stop reliving in a sadomasochistic manner their experience of being abused, hurt, tortured by men. Their rancor and hate for the stronger sex explain their conscious, more probably subconscious desire to revenge themselves on men - even to castrate or kill them - and their desperate attempts to prove that females can be crueler and more cynical than males; this is their way to remove even the slightest doubt in what concerns a woman's inner potential. According to the ancient myth, the Amazons mated with their neighbours once a year and solely for reproduction, which implicates their frigidity; killing their own helpless new-born sons may implicate that motherhood was incom patible with their way of life, in addition to their hostile attitude to men.

A close analysis of the Amazons' behaviour pattern - their sadism towards themselves (cauterizing their right breasts in adolescent age) and their own children, using men's clothes as mummery attributes, disguising themselves as men - shows their true nature; according to Aristotle, such a woman is viewed as ' a maimed.., mutilated man' [9, p. 41]; moreover, C. Jung suggests that the dark side of subconsciousness (the Shadows), described in the myths about the Amazons, triumphs when we deal with mass psychosis - the Inquisition, the Bolshevik regime, Nazism, and suchlike phenomena; the Shadows fill the nights of a person with horrible dreams and break through into the real world determining the actions of those possessed by them; and the leader is always the least responsible person with the worst character traits, the one generally guided by primitive instincts of violence and cruelty [18, p. 57-58]. An Amazon is a gregarious being, her tribe is a single-sex society; it encourages a predatory attitude towards the world around her; the dominant manifestation of such philosophy is permanent bloodshed and ostentatious cruelty.

The $20^{\text {th }}$ century literature (especially the products of mythological mentality) often addresses the gender issues. The body of a character may be regarded as the ID of his/her soul, a kind of identification code of a character's spirit; that is why special attention is given to his/her descent, name, marital and family status, repressed or excessive sexuality, bloody magic rituals aimed at ensuring optimal space for gaining strength, self-assertion, or for realizing the plans of the evil forces, whose puppet a person consciously or unwittingly becomes. Under such circumstances, males and females act differently; and for a reader, their bodies may become an identification sign of their inner essence.

For instance in Sad Hetsymans'kyi (The Garden of Gethsemane), a novel by Ivan Bahrianyi, protagonist Andrii Chumak suddenly realizes that some of the omnipotent investigators suffer more than those they torture during interrogations.

'In the house on the opposite side of the jail's courtyard, where there lived the high-ranking NKVD** officials, very thick boards were sticking out of one of the windows; they were tied together with a length of rope and moored to the upper frame; someone had constructed the bunk, and now he was trying to lie on it... Apparently, after a hellish night, after all the cries and moaning, after the crazy music of the 'production lines', after this 'work' of his, the investigator could not go to sleep in a normal way, as all people do, in a bed... He had

\footnotetext{
${ }^{*}$ hic sunt leones - literally, here are lions; the phrase was used to mark strange lands on ancient maps.

** NKVD (Russian - Narodnyi Komissariat Vnutrennikh Del) - the People's Commissariat for Internal Affairs.
} 
wrapped a bed sheet around his waist and tied himself to the boards fearing he would fall down in his sleep; it looked as if he was asleep ... He was jerking in his sleep, gesticulating with his arms, wriggling ... That washow he slept. A man with sick psyche. Andrii thoughtback of the 'factory-kitchen' with all its madness, and he understood the poor devil' [4, p. 247]. At the same time, Melnyk, a jailer, surprises a reader; the man seems to be the only one who still has some human qualities - empathy, mercy to the prisoners; sometimes at a great risk to himself, he even passes cigarettes to the poor people. At the end of the novel, a reader learns that the 'kind' jailor (who looks like a monster, which means that he is, a priory, a flawed creature) is an executioner; bearing a friendly and sympathetic smile, he shoots the doomed and finishes off the wounded with a small iron bar; a reader sees a typical sadist, whose greatest pleasure is to watch the agony of his tormented, deceived, desperate, scared victims.

In the novel, the elements naturalism contribute to the theme of corporeality; in my opinion, the female chekists* dispay the behavioural traits ascribed to the Amazons; they derive vampiric pleasure from their 'work' in the Stalin jails depriving the incarcerated men of their manhood. Describing the death of Yahelskyi, a former member of the Party troika**, Ivan Bahrianyi gives a vivid description of the castration. 'Hit him with boards, with boards! And Nechaieva - with a ram rod - on his b...! Kundibundi*** $^{* * *}$ on the big production line' [4, p. 80]. To paraphrase Hermann Hesse, every person is more than just them selves; the message of the aphorism is that a person as a holistic being is a product of society he or she belongs to; unfavourable conditions like wars and revolutions provoke an upsurge in negative phenomena, Amazonism and prostitution in women in particular. The myth provides quite an accurate account of these phenomena. We should remember that 'profane spaces are always gaps in sacred spaces, which belong to the distant past' [16, p. 107]; in these infernal craters - passages for strong currents from the other world - a woman, who in the sacred space would remain herself, receives an evil incarnation. According to E. Fromm, choosing between 'to be' and 'to have', she gives preference to the surrogate postulate 'to have' substituting the false for the true, easily accessible things for the true values.

In his novel Tigrolovy (The Tiger Trappers), Ivan Bahrianyi describes the Khabarovsk whores - the daughters of Ukrainian kulaks deported to Siberia. The frost is hard, it is thirty degrees below zero (-22 degrees Fahrenheit), but the girls in a restaurant wear no stockings. Hryhorii Mnohohrishnyi and Hrytsko Sirko feel sorry for them; for the trappers, the exposed flesh is the sign of poverty; they think the girls have no money to buy stockings or cottonwool trousers. For a modern reader, the implication is obvious - this form of body language signals belonging to one of the oldest professions.

The Bolshevik epoch brought defilement and licentiousness to the land of Ukraine. In the works of T. Osmachka, the 'troublous' times (the war, the revolution, the Bolshevik power in the Ukrainian villages, the collectivization - desecration of the conquered land, stripping women of their dignity, pollution of the Ukrainian gene pool with the alien seed) are described in terms mythology as a threatening, an overtly scary, infernal phenomenon. The gang rape of a young teacher by the Red Army soldiers of Tula in T. Osmachka's novel Rotonda Dushohubtsiv (The Rotunda of Murderers) is presented not as an individual act of violence, but as a mythological picture - the Russian soldiers molest an educated girl, who is perceived as the personification of Ukraine. The author contrasts the victim - her national clothes, her high spirituality, her delicate charm, which is inconspicuous in comparison with the bright beauty of the other village girls - and the lusty soldiers who sing a rude, arrogant song. At the same time, we cannot ignore the fact that any war seriously affects sexual relations. In The Rotunda of Murderers, Hapusia Shelestiian, an underage girl and a potential victim, gets into an extremely difficult, tragic situation. She has to work as a hired hand for Madzyhon in exchange for her family using a pair his of horses. Scared into obedience by the blackmail of the party bastard, who threatens to arrest her father and keep him rotting in jail, the fourteen-year-old girl cannon resist the rapist; she only suggests a compromise dropping a clear hint about a love game - incomplete sexual intercourse, which

\footnotetext{
* chekist - a member of Cheka (Russian - Chrezvychaynaya komissiya) - Emergency Committee, the Soviet state security organization.

troika - in the Soviet Union history, the commission of three persons who issued sentences to people after simplified investigations and without a full trial.

kundi-bundi - tortures (Russian convict lingo).
} 
is indirectly referred to in folk song about pre-marital relations; in some villages it is known as the prytuly custom. It turns out, old Shelestiian has nothing against such relationship between the master and his servant; he considers it quite acceptable under the circumstances - for him, the horses are more important than his child's safety. Neither his parental intuition nor typical peasant cautiousness nor even the unenviable fate of Madzyhon's previous servant stops Shelestiian from making a risky deal. His daughter's tragedy does not cause any emotional outburst - just a submissive acceptance of the fact, a weak verbal condemnation, not even a thought of revenge - complete capitulation to a cruel twist of the fate.

The level of Madzyhon's morality (he is the headmaster of the local school and the head of the Kutsiv Party committee) is vividly shown in the scene with the dog. Bestiality is strictly prohibited by God's law. 'Also you shall not have intercourse with any animal to be defiled with it, nor shall any wom an stand before an animal to mate with it; it is a perversion' [7, p. 123] (Leviticus 18:23). According to the Bible, is a cardinal sin punishable by death. 'If there is a man who lies with an animal, he shall surely be put to death; you shall also kill the animal' [7, p. 125] (Leviticus 20:15).

Madzyhon wakes up Hapusia, who thinks that after what the old bastard has done to her, there is no sense in coming back home, and hastily turns the dishonoured girl out of the house; but he orders her to let in the dog, which has been scratching at the door for a long time; the dog joyfully jumps onto his bed. The author draws a bitter conclusion: '... the times have come ... when a poor person is valued less than even a dog' $[12$, p. 61]. At the same time, T. Osmachka presents the defilement as a grotesque phenomenon. The exaggeration of sexual abuse of Ukrainian women - as a mythological collision highlights the tragedy of the nation whose gene pool is being polluted by the invaders; they try to impose on Ukraine the inferior status of the concubine, to destroy or reduce to minimum the masculine element. Actually, this is a subconscious aim of all colonialists; in literature, the body language of certain characters reveals their true intentions.

In Ivan Bahrianyi's Defeat, the cynical song of the German soldiers is very im plicative:

'Война пріма, война гуm!

The war is prima, the war is gut!

Фрау дома, фройлян тут' [3, р. 37]

Frau at home, Fräulein here'.

From the mythological perspective, the meaning of such brutal war songs is deeper than their primitive form may suggest - in wartime, all men who are in the army, whatever their marital status, are regarded as single - the bridegrooms of death. In his other work, Liudyna bizhyt nad prirvoiu (A Man Runs Over a Gulf ), Ivan Bahrianyi describes a pornographic scene, which does not seem to fit into the novel's composition. A reader has to infer the implicated meaning - the infernal essence of the young mistress of the chekists; the shameless girl takes a satanic pleasure in dem onstrating her gorgeous body to Kolot, who is doomed to interrogation, torture, and death. '... a disorderly bed with many scattered pillows and the crumpled featherbed; a half-naked girl spread her body leisurely over the bed lying exactly as she had been left, dizzyingly passionate embraces had obviously driven to the oblivion of sleep ... The girl sat up, stretched with pleasure, lowered her naked legs down on the floor, and got out of bed. For another moment, she was standing in front of Maksym in nothing but a short underwear shirt; she did not seem to notice him' [1, p. 105]. As mythology would have it, stripping a person of his/her clothes indicates that the person is of no value for the community; a naked person receives the status of an outcast; allowing others to see one's nakedness is associated with death; thus Ivan Bahrianyi's text implicates the idea that war is total lawlessness.

It has been stated above that bodily flaws, apart from being negative signs, can indicate that a person is chosen for a special mission in life. A disabled artist Fedir Dziuba (the novel Rai (Paradise) by Vasyl Barka) takes a great personal risk creating a sculpture which symbolizes independent Ukraine. And in Ivan Bahrianyi's novel Marusia Bohuslavka, another deformed artist looks for a model for the image of Ukraine and chooses a girl of loose morals contemptuously called 'the general line'* because

\footnotetext{
${ }^{*}$ the general line (or the general line of the Party) - a cliché: the directives of the governing bodies of the Communist Party.
} 
she serves as a prostitute for high-ranking city officials; once, she was a daughter of a merchant, or even a bishop; then there happened things she could not change, and they drastically affected her life.

'... < she $>$ fell from the highest heights ... to the very bottom of the tragic reality, one could not fall lower, she fell into the category of the "socially alien element", the "class enemy", "the former"' [6, p. 140]. At first glance, the author's attitude to the character is condescendingly sympathetic; but then he draws a clear conclusion: 'She is a tragic personification of the whole lost generation thrown down to the bottom of society, and they can rise ... only paying that price ...' [6, p. 140]. This is what Liudmyla Bohomazova (Marusia Bohuslavka) and the whores in a restaurant - the daughters of rich farmers deported to Siberia (The Tiger Trappers) have in common.

'The girls were talking in Ukrainian!.. They try to survive hunger and cold, lawlessness and death; they survive at the expense of beauty and youth, honour and the happiness of motherhood' [5, p. 189190]. Though there is also a difference between the characters; if it were not for the scene with a different Liudmyla Bohomazova - the one painted by hunchbacked Danylo Shyhymaha, a reader would perceive the girl's tragedy solely from the social class perspective.

The actors are impressed with the masterpiece, and the other characters suddenly see the girl as the personification of female beauty, the apotheosis of grief.

'Olha gasped quietly, Ata managed to control herself, but yelped inwardly... On the stand, there stood - Liudmyla Bohomazova! But - what a girl! Unspeakably beautiful. Not the Liudmyla Bohomazova everyone knew, a lost soul, a despised 'general line', but ... heavenly exquisite. As sad and pure as an angel!.. Her features reflected the human soul purified through sorrow and tragedy ... The soul that belongs to God...' [2, p. 290]. Together with Ataleia, a reader realizes that the artist has put his heart in the work, that he loves this girl, whose reputation has been destroyed by the high-ranking libertines, and in this case, the Domain of Art is higher than the Domain of Morality - what matters is not the attitude of the society described in the book, but the vision of the sculptor. Marina Tsvetaeva once said that to love means to see a person as God intends them to be, not the one born of their parents and created by the circumstances around them [8, p. 289]. Consider also the opinions of other outstanding people. According to Federico Fellini, the human civilization keeps expressing itself through art; Vasyl Barka believes that Heaven can be embodied only in art, which is why art is above all worldly treasures.

The human body becomes an important mythologem not only in prose, but in poetry as well. In Yevhen Malaniuk's poem, the pose of a raped, repressed, defeated, probably even dead woman - the personification of Ukraine - is quite symbolic:

'На узбіччі дороги - з Європи в Азію,

'By the side of the road - from Europe to Asia,

Головою на Захід і лоном на Схі -

With her head towards the West and her legs towards the East -

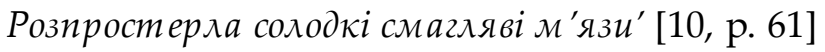

$<$ She $>$ has spread out her sweet tan muscles'.

Obviously, the pose of the character is an allegory of the Ukrainians' intellectual longing for European civilization (the fact has been proved more than once) and the bodily, animal, masochistic paradigm of submissiveness, some kind of pathological servility of the nation, which has been a colony for ages, the desire to physically belong to the Eastern invader. Though there is a different interpretation of the image. Yevhen Malaniuk describes Ukraine not only as the bastard mother of Janissaries' ('байстрюча мати яничар' [10, p. 87]), but also as sinister swan-maiden Obida [10, p. 86], one of the most ominous pagan gods, and even as the witch from the famous Viy by Gogol.

'А може, й не Eллада Cmепова?

'Maybe <she $>$ is not Steppen-Hellas?

Аиш відьма-сотниківна мертва й гарна,

\footnotetext{
${ }^{*}$ Viy - the name of the demonic entity.
} 
$<$ Maybe she is $>$ Just a witch, the Sotnyk's* daughter, dead and beautiful, Що чорним ядом серие напува

Who fills the heart with black poison

I опівночі воскресає марно ...

And wakes from the dead at midnight - but all in vain ...

Труна свистить, колуючи, а Вій

Her coffin circles whizzing through the air, and Viy

Залізні вже розплющуе зінниці.

Is already raising his iron eyelids.

Півнів не чут в. I в мутній голові

The roosters are quiet. And in the dazed mind,

Горить одне: щзо все цุе - ні! - не сниться' [10, p. 75-76]

One thought is burning: no! - it is not a bad dream'.

Thus the contexts of the thematically close poem s indicate that in the already cited Za doboiu - doba. Za eroiu - era (The Succession of Epochs and Eras), which may be taken as a starting point for the discussion, the author describes the pose of the dead 'lustful Scythian hetaera' ('похотлт ива скитська zетера' [10, p. 61]); the idea agrees with the archaeological finds (after all, in modern Ukrainian cemeteries, the dead are typically buried with their heads towards the West).

In Oleh Olzhych's Antropolohiia (Anthropology), the hologram of the hum an body is presented from both personal and national perspectives.

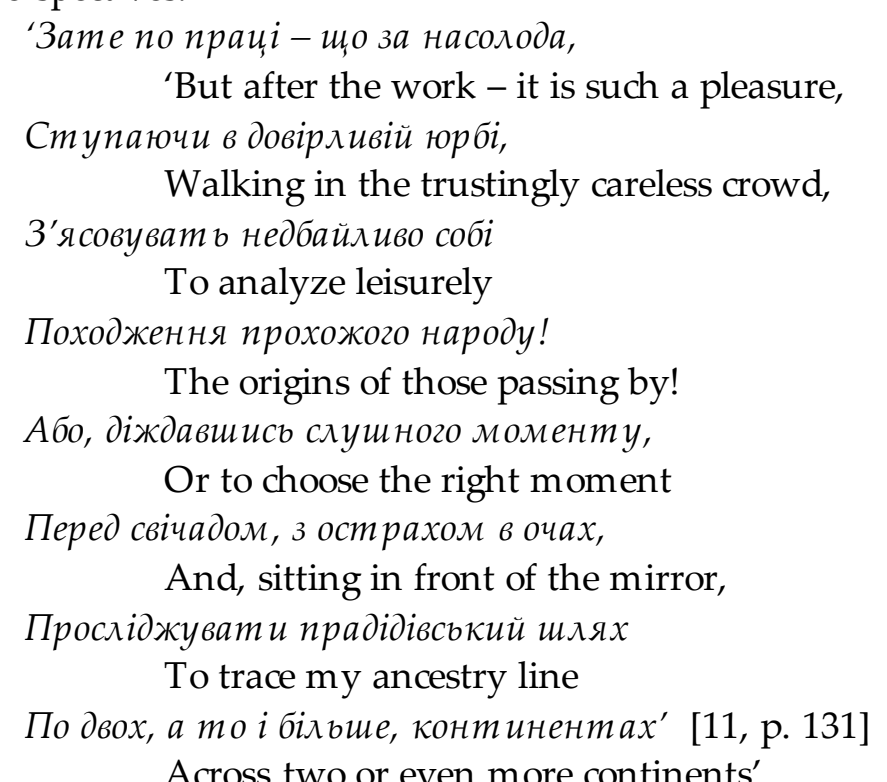

Walking in the crowd, sitting in front of the mirror, the character analyzes the forms of skulls; the process, in my opinion, can be compared to a reader's analysis of a literary text - looking for similar contexts in the lives of the characters and in one's own life, for the values the character and a reader may share; the subconscious inferences from the text, comprehension of its deep underlying ideas are the main, inherent elem ents of this process; without them, a literary text cannon exist. Unfortunately, in most cases, critics do not try to overcome dogmatic inertia and view the implications made by literary works from the spatial perspective, though such implications have all the essential features of a temporal phenomenon.

In terms of the methodology of archetypal criticism, corporeality and the hologram of the hum an body in literary texts are regarded as a powerfully charged informative concept. The verbal and nonverbal forms of its expression (clothes, emotional expression, the use of the human body in order to convey certain meanings in folk culture, rituals, magic rituals, folklore), the body that is on the border of the norm (otherness, difference, ugliness, deformity, disability), the body of an 'alien', the body as a

\footnotetext{
* Sotnyk - a high-ranking officer in the Cossack army.
} 
sign of being 'alien' or a sign of 'alien hostility', the body beyond the norm (a shocking, scary, repulsive, freaky body; death, illness, pain; a corpse, a mutilated body), sexuality as an instrument of provoking the other characters (and a reader), the body as a mythologem, a prime, a frame - all these are important and nonreplaceable markers of a literary character; they are inherent in any literary text as an indirect manifestation of the author's attitude.

\section{REFERENCES}

[1] Багряний І. Аюдина біжить над прірвою. Український письменник, К., 1992.

[Bahrianyi I. Liudyna bizhyt nad prirvoiu. Ukrainskyi pysmennyk, K., 1992.]

[2] Багряний I. Маруся Богуславка. В: Багряний І. Буйний вітер. Мюнхен, Україна, 1957, 7 - 423.

[Bahrianyi I. Marusia Bohuslavka. In: Bahrianyi I. Buinyi viter. Miunkhen, Ukraina, 1957, 7 - 423.]

[3] Багряний I. Розгром: повість-вертеп. Прометей, Ульм, Нью-Йорк, 1948.

[Bahrianyi I. Rozghrom: povist-vertep. Prometei, Ulm, Niu-York, 1948.]

[4] Багряний I. Сад Гетсиманський. Дніпро, К., 1992.

[Bahrianyi I. Sad Hetsymanskyi. Dnipro, K., 1992.]

[5] Багряний І. Тигролови: роман та оповідання. Молодь, К., 1991.

[Bahrianyi I. Tyhrolovy: roman ta opovidannia. Molod, K., 1991.]

[6] Барка В. Рай / Василь Барка. Свобода, Джерсі-Сіті, Нью-Йорк, 1953.

[Barka V. Rai / Vasyl Barka. Svoboda, Dzhersi-Siti, Niu-York, 1953.]

[7] Біблія. М., [Б. в.], 1990.

[Bibliia. M., [B. v.], 1990.]

[8] Кожевников А., Аиндберг Т. Вечные мысли о главном: афоризмы: Восток. Россия. Запад. СПб., Издательский Дом “Нева”, 2005.

[Kozhevnykov A., Lyndberh T. Vechnye mysly o hlavnom: aforyzmy: Vostok. Rossyia. Zapad. SPb., Yzdatelskyi Dom "Neva", 2005.]

[9] Гитин В. Эта покорная тварь женщина. Торсинг, М., 2002.

[Hytyn V. Eta pokornaia tvar zhenshchyna. Torsynh, M., 2002.]

[10] Маланюк С. Поезї. К., Український письменник, 1992.

[Malaniuk Ye. Poezii. K., Ukrainskyi pysmennyk, 1992.]

[11] Ольжич О. Цитаделя духа. Словацьке педагогічне вид-во, Братислава, 1991.

[Olzhych O. Tsytadelia dukha. Slovatske pedahohichne vyd-vo, Bratyslava, 1991.]

[12] Осьмачка Т. Ротонда душогубиів. Торонто, 1956.

[Osmachka T. Rotonda dushohubtsiv. Toronto, 1956.]

[13] Платон. Законы. В: Платон. Сочинения: 83 m., Т.3, Ч.2. Мысль, М., 1972, 83 - 478.

[Platon. Zakony. In: Platon. Sochynenyia: v 3 t., T.3, Ch.2. Mysl, M., 1972, 83 - 478.]

[14] Суковата В. Гендер і релігія. В: Агєєва В., Кобелянська А., Скорик М. (Ред.) Основи теорії тендеру. K.I.C., K., 2004, $385-425$.

[Sukovata V. Gender i relihiia. In: Ahieieva V., Kobelianska L., Skoryk M. (Red.) Osnovy teorii tenderu. K.I.S., K., 2004, 385 - 425.]

[15] Фромм Е. Мати чи бути? Український письменник, К., 2010.

[Fromm E. Maty chy buty? Ukrainskyi pysmennyk, K., 2010.]

[16] Хайдеггер М. Искусство и пространство. В: Гальцева Р. (Ред.) Самосознание культуры и искусства ХХ века. Университетская книга, СПб., Кудьтурная инициатива, М., 2000, 105 - 113.

[Khaidehher M. Yskusstvo y prostranstvo. In: Haltseva R. (Red.) Samosoznanye kultury y yskusstva XX veka. Unyversytetskaia knyha, SPb., Kulturnaia ynytsyatyva, M., 2000, 105 - 113.]

[17] Юнг К. Архетип і позасвідоме. (Світло світогляду). Український письменник, К., 2014.

[Iunh K. Arkhetyp i pozasvidome. (Svitlo svitohliadu). Ukrainskyi pysmennyk, K., 2014.]

[18] Юнг К. Борьба с тенью. В: Юнг К. Избранное. Попурри, Минск, 1998, 53 - 64.

[Iunh K. Borba s teniu. In: Yunh K. Yzbrannoe. Popurry, Mynsk, 1998, 53 - 64.] 
[19] Emil G. Hirsch, Schloessinger M. Horns of Moses. In: Jewish Encyclopedia: The unedited full-text of the 1906 Jewish Encyclopedia. Available at: http://www.jewishencyclopedia.com/articles/7869-horns-of-moses.

Address: Olha Slonovska, Vasyl Stefanyk Precarpathian National University, 57, Shevchenko Str., IvanoFrankivsk, 76025, Ukraine.

E-mail: olha.slonovska@pu.if.ua.

Received: 21.07.2017; revised: 29.09.2017.

Слоньовська Ольга. Тілесність як голограма міфологічного змісту (на матеріалі прози української діаспори 20 - 50-х років). Журнал Прикарпатського університету імені Василя Стефаника, 4 (2) (2017), 7078.

У статті розглядається питання роді й місця художньої правди і художнього домислу. Велику увагу приділено міфопоетичній голограмі людського тіла як носію інформації і цілого блоку важдивих маркерів.

Ключові слова: дітературний текст, міфопоетична голограма тіла, інструментарій архетипної критики, еротика. 